\title{
Long-term Effect of Insulin on Glucose Transport and Insulin Binding in Cultured Adipocytes from Normal and Obese Humans with and without Non-Insulin-dependent Diabetes
}

\author{
Madhur K. Sinha, Lucy G. Taylor, Walter J. Pories, Edward G. Flickinger, Diane Meelheim, \\ Samuel Atkinson, Narinder S. Sehgal, and José F. Caro \\ Departments of Medicine, Surgery, and Obstetrics and Gynecology, School of Medicine, East Carolina University, \\ Greenville, North Carolina 27834-4354
}

\begin{abstract}
We have tested the hypothesis that in vitro exposure of insulin-resistant adipocytes with insulin results in improved insulin action. A primary culture system of adipocytes from obese subjects with or without non-insulin-dependent diabetes mellitus (NIDDM) and nonobese control subjects has been developed. The adipocytes when cultured in serum-free medium do not lose their original characteristics in regard to insulin binding and glucose transport. The adipocytes from three groups were incubated with insulin $\left(0,10^{-10} \mathrm{M}\right.$, and $\left.10^{-7} \mathrm{M}\right)$ for $24 \mathrm{~h}$ at $37^{\circ} \mathrm{C}$, receptor-bound insulin was dissociated, and basal and insulin $\left(1 \times 10^{-11}-10^{-7} \mathrm{M}\right)$-stimulated glucose transport and ${ }^{125}$ I-insulin binding were determined. The 24-h insulin exposure of adipocytes from control subjects decreased basal and insulin-stimulated glucose transport. The effects of $1 \times 10^{-7} \mathrm{M}$ insulin were more pronounced than $1 \times 10^{-10} \mathrm{M}$ insulin. Similarly, insulin exposure decreased insulin sensitivity and responsiveness of cultured adipocytes from obese and NIDDM patients. The insulin-induced reduction in insulin sensitivity and responsiveness for glucose transport in three groups were due to alterations at insulin binding and postbinding levels. In conclusion, insulin induces insulin resistance in control adipocytes and further worsens the insulin resistance of adipocytes from obese and NIDDM subjects. For insulin to improve the insulin resistance of adipocytes from NIDDM patients, either more prolonged in vitro insulin exposure and/or other hormonal factors might be required.
\end{abstract}

\section{Introduction}

Insulin resistance in obesity and non-insulin-dependent diabetes mellitus (NIDDM) ${ }^{1}$ is characterized at the cellular level

This paper was presented in part at the joint conference of the American Diabetes Association and the North American Association for the Study of Obesity, Toronto, Canada, 1985.

Address reprint requests to Dr. Sinha, Dept. of Medicine, ECU School of Medicine, Greenville, NC 27858-4354.

Received for publication 24 November 1986 and in revised form 23 April 1987.

1. Abbreviations used in this paper: GTT, glucose tolerance test; KRB, Kreb's-Ringer bicarbonate; NIDDM, non-insulin-dependent diabetes mellitus; obese NGTT, morbidly obese subjects with normal GTT; obese NIDDM, morbidly obese patients with NIDDM.

J. Clin. Invest.

(c) The American Society for Clinical Investigation, Inc.

0021-9738/87/10/1073/09 \$2.00

Volume 80, October 1987, 1073-1081 by both binding and postbinding defects. The overall insulin resistance in NIDDM, with or without obesity, has been well demonstrated with the use of several in vivo techniques (1-6). Insulin therapy of NIDDM subjects improves insulin sensitivity and responsiveness of peripheral glucose utilization as assessed by glucose clamp techniques (7-9). Several of the abnormalities of carbohydrate and lipid metabolism in isolated adipocytes from NIDDM patients have also been shown to improve with insulin treatment $(10,11)$. These in vivo and in vitro studies suggest that insulin improves the insulin sensitivity and responsiveness of peripheral tissues. Enhanced insulinstimulated glucose transport with decreased or unaltered sensitivity have also been reported in isolated adipocytes from experimentally induced chronic hyperinsulinemic rats (12-14) or hyperinsulinemic young obese Zucker rats $(15,16)$. Thus, it is likely that insulin sensitizes the insulin-resistant adipocytes. Whereas, it desensitizes the normal adipocytes and the evidence to support this contention is overwhelming in various animal cell models (17-24). To test these hypotheses directly, we have developed a primary culture system for insulin-responsive human adipocytes from control and morbidly obese subjects with or without NIDDM. Using this system, we determined the effects of a 24-h exposure of $1 \times 10^{-10}$ and 1 $\times 10^{-7} \mathrm{M}$ insulin on insulin sensitivity and responsiveness of glucose transport and insulin binding.

\section{Methods}

Materials. The carrier-free ${ }^{125} \mathrm{I}-\mathrm{Na},{ }^{3}-\mathrm{O}-\left[{ }^{14} \mathrm{C}\right]$ methyl-D-glucose $(58.0$ $\mathrm{mCi} / \mathrm{mmol}), \mathrm{L}-\left[\mathrm{U}-{ }^{14} \mathrm{C}\right]$ leucine $(300 \mathrm{mCi} / \mathrm{mmol})$, and [U- $\left.{ }^{14} \mathrm{C}\right]-\mathrm{D}-\mathrm{glu}-$ cose $(260 \mathrm{mCi} / \mathrm{mmol})$ were obtained from New England Nuclear, Boston, MA. Crude collagenase (type I, batch 43 B 216) was obtained from Worthington Biochemicals, Freehold, NJ. Fraction V bovine serum albumin (BSA) was obtained from Armour Pharmaceutical Co., Kankakee, IL, and it was further purified by charcoal treatment (25). Crystalline porcine insulin was kindly provided by Dr. Ronald Chance of Eli Lilly \& Co., Indianapolis, IN. All other chemicals were reagent grade.

Human subjects. 16 morbidly obese patients with NIDDM and an equal number of morbidly obese patients without diabetes were studied. The clinical and biochemical data of these patients are presented in Table I. These patients were admitted to the hospital to undergo gastric bypass for the treatment of morbid obesity. Nonobese-nondiabetic subjects were used as the control group. These subjects had uncomplicated gallstone disease and were admitted for elective cholecystectomy, or were patients undergoing abdominal hysterectomy. The biochemical data of these two clinically different subgroups of nonobese subjects were identical. Thus, they have been combined and referred to as the control group. The characteristics of the control group were as follows: age, $37.3 \pm 2.8 \mathrm{yr}$; sex, three male, fifteen female; weight, $65.8 \pm 2.4 \mathrm{~kg}$; height, $163 \pm 6 \mathrm{~cm}$; fasting plasma glucose, $96 \pm 3 \mathrm{mg} / \mathrm{dl}$; and fasting plasma insulin, $12 \pm 2 \mu \mathrm{U} / \mathrm{ml}$. The mean fat cell colume was $374 \pm 30 \mathrm{pl}$. 
Table I. Clinical and Biochemical Data of Obese Patients Studied

\begin{tabular}{lcc}
\hline & Nondiabetic & NIDDM \\
\hline $\begin{array}{l}\text { Number } \\
\text { Sex }\end{array} \quad 16$ & 16 \\
$\quad$ Female & 14 & 13 \\
$\quad$ Male & 2 & 3 \\
Age $(y r)$ & $37 \pm 4$ & $40 \pm 2$ \\
Weight $(k g)$ & $122 \pm 5$ & $124 \pm 5$ \\
Height $(\mathrm{cm})$ & $168 \pm 3$ & $165 \pm 2$ \\
Body Fat $(\%)$ & $48 \pm 1$ & $49 \pm 1$ \\
Adipocytes volume $(p l)^{*}$ & $789 \pm 45$ & $801 \pm 74$ \\
Fasting glucose $(m g / d l)$ & $94 \pm 4$ & $208 \pm 16^{\S}$ \\
Rate of glucose & $1.2 \pm 0.1$ & $0.5 \pm 1^{\S}$ \\
$\quad$ disappearance & & \\
$\quad$ (\%/min) & & \\
Fasting insulin $(\mu U / m l)$ & $35 \pm 5$ & $39 \pm 5$ \\
Duration of obesity $(y r)$ & $17 \pm 4$ & $20 \pm 4$ \\
Duration of diabetes $(y r)$ & & $3.0 \pm 0.7$ \\
Treatment of diabetes & & Insulin (5) \\
$\quad$ (No. of patients) & & Sulfonylureas (6) \\
& & None (5) \\
\hline
\end{tabular}

* Mean values from eight subjects.

${ }^{\ddagger}$ After intravenous GTT ( $\left.25 \mathrm{~g}\right)$.

$P<0.01$

With the exception of the obesity and NIDDM, none of the subjects studied had any diseases or had taken any medications known to alter carbohydrate metabolism.

All subjects had maintained constant body weight during the months preceding admission. Records of food intake of the morbidly obese patients demonstrate that $\sim 15 \%$ of the calories were derived from proteins, $39 \%$ from fat, and $49 \%$ from carbohydrates, which is the typical distribution of calories for this population of patients in North Carolina (26). Because of the effect that the caloric intake and its distribution might have on this study, morbidly obese patients studied were admitted into the hospital $4 \mathrm{~d}$ before surgery. During this period, they remained active at approximately their prehospital exercise level. They received a weight-maintaining diet providing $50 \%$ of the calories as carbohydrates, $30 \%$ as fat (polyunsaturated/saturated fat ratio of 0.4 and cholesterol content of $600 \mathrm{mg}$ ), and $20 \%$ as protein. This diet was basically the same as the one that the patients were consuming as outpatients.

Every morbidly obese patient without known diabetes mellitus had a 75-g oral glucose tolerance test (GTT) as an outpatient. Their carbohydrate intake was $>150 \mathrm{~g}$ daily for the preceding $3 \mathrm{~d}$ before the test. The criteria of the National Diabetes Data Group (27) was used to classify these patients as nondiabetics. Oral glucose tolerance tests were not performed in the morbidly obese patients with diabetes with the exception of one who was not known to have NIDDM, but had a fasting plasma glucose of $282 \mathrm{mg} / \mathrm{dl}$ and a peak glucose of $429 \mathrm{mg} / \mathrm{dl}$ during the test. The morbidly obese subjects with or without NIDDM had a 25-g intravenous GTT as outpatients to determine the rate of glucose disappearance of plasma glucose and insulin (28). Eight of these subjects had the intravenous GTT repeated the 3rd d of their hospitalization, while they were on a controlled diet as described above. Insulin or oral hypoglycemic agents were discontinued before admission into the hospital. Rapid-acting insulin was used only if the preprandial plasma glucose was $>300 \mathrm{mg} / \mathrm{dl}$. The subjects underwent surgery after an overnight fast. General anesthesia was induced with a short-acting barbiturate, and maintained by phentanyl and nitrous oxide-oxygen mixture. Only saline was given intravenously before the subcutaneous fat biopsy. After exploring the abdomen, $\sim 10 \mathrm{~g}$ subcutaneous fat was obtained through midline incision. Informed written consent was obtained from all patients after the nature and potential risks of the study had been explained.

Isolation of human adipocytes. Isolated human adipocytes were prepared by the collagenase digestion method of Rodbell (29), as modified for human adipose tissue by Pedersen et al. (30). Since in many experiments we maintained isolated human adipocytes in primary culture for $24 \mathrm{~h}$, the entire procedure of cell isolation was performed under strict sterile conditions. The fat biopsy was transferred from the surgical unit to the laboratory in 3\% BSA-medium 199 containing penicillin $(100 \mathrm{U} / \mathrm{ml})$ and streptomycin $(100 \mu \mathrm{g} / \mathrm{ml})$. The tissue was washed three times in sterile phosphate-buffered saline and the majority of the connective tissue and blood clots were removed. The tissue was cut into small pieces of $\sim 1 \times 2 \mathrm{~mm}$ size and suspended in $10 \mathrm{mM}$ Hepes-Kreb's-Ringer bicarbonate (KRB) buffer (pH 7.4) containing $3 \%$ BSA, $5 \mathrm{mM}$ glucose, and $0.5 \mathrm{mg} / \mathrm{ml}$ collagenase in plastic Erlenmeyer flasks. The ratio of tissue and collagenase buffer was 1:2 wt/vol. The tissue was gently digested for 45-60 min in an Orbit water bath shaken at $150-160 \mathrm{cycle} / \mathrm{min}$ at $37^{\circ} \mathrm{C}$ in a $95 \% \mathrm{O}_{2} / 5 \% \mathrm{CO}_{2}$ atmosphere. After digestion, the suspension was filtered twice through nylon mesh and washed four times with $10 \mathrm{mM}$ Hepes-KRB buffer (pH 7.4) containing 3\% BSA and $5 \mathrm{mM}$ glucose. The washing was performed by allowing the cells to settle under gravity, and the buffer was removed using a $31 / 4$ " spinal needle or by $5-\mathrm{s}$ centrifugation at $50 \mathrm{rpm}$ in a Dynac centrifuge. The cells were finally suspended at $50 \%$ lipocrit in the assay buffer. The adipocytes were fixed at $10 \%$ lipocrit in $10 \%$ formalin-buffered saline for $24 \mathrm{~h}$. 5- $\mu \mathrm{l}$ aliquots of fixed cells were counted and diameter of cells was determined using a grid in the eyepiece of the microscope. The mean cell diameter and cell volume were calculated by computer analysis using average diameter and its standard deviation (31). Since these data were not immediately available, the experiments were performed based on percent lipocrit of cell suspension.

We have tested several batches of collagenase from Sigma Chemical Co., St. Louis, MO, and Worthington Biochemical Corp., Freehold, NJ. Collagenase (Worthington Biochemical Corp.), type I (batch 43 B 216), gave maximally insulin-responsive adipocytes for glucose transport. With this particular batch of collagenase $(0.5$ $\mathrm{mg} / \mathrm{ml}$ ), digestion of fat tissue was complete and the lysis, as evidenced by the ratio of floating triglycerides and intact cell volume, was negligible $(<5 \%)$ in both control as well as fat tissue from morbidly obese patients. No preferential breakage of larger fat cells during the isolation procedure seemed to occur as the ratio of mean fat cell volume between control $(376 \pm 30 \mathrm{pl})$ and morbidly obese $(790 \pm 54 \mathrm{pl})$ subjects was similar to those reported by Hirsch and Batchelor (32) in the intact adipose tissue pieces between nonobese and morbidly obese subjects.

Glucose transport in adipocytes. Glucose transport in fat cells was measured by determining the uptake of $\left[{ }^{14} \mathrm{C}-\mathrm{U}\right] \mathrm{glucose}$ at tracer concentrations as described by Kashiwagi and co-workers (33). These investigators have validated this method for measuring glucose transport in comparison to 3-O-methyl glucose uptake in nondiabetic as well as in diabetic subjects (11). The basal and insulin $\left(10^{-10}\right.$ and $10^{-7} \mathrm{M}$ )stimulated glucose transport measured by two different isotopes, i.e., $\left[{ }^{14} \mathrm{C}\right.$-U]glucose (33) and $\left[{ }^{14} \mathrm{C}-3-O-m e t h y l\right]$ glucose $(34)$ were comparable in our morbidly obese subjects with or without NIDDM. The fat cells at $20 \%$ lipocrit $(\approx 200,000$ cells $/ \mathrm{ml})$ were incubated with $500 \mathrm{nM}$ $\left[{ }^{14} \mathrm{C}\right.$-U]glucose in the absence and presence of varying insulin concentration $\left(1 \times 10^{-11}-10^{-7} \mathrm{M}\right)$, for $1 \mathrm{~h}$ at $37^{\circ} \mathrm{C}$ in a $95 \% \mathrm{O}_{2} / 5 \% \mathrm{CO}_{2}$ atmosphere in $10 \mathrm{mM}$ Hepes-KRB buffer (pH 7.4) containing $3 \%$ BSA. The cells were then separated by centrifuging through silicone oil and ${ }^{14} \mathrm{C}$-radioactivity associated with cells was counted.

Insulin binding in adipocytes. Insulin was radiolabeled with ${ }^{125} \mathrm{I}-\mathrm{Na}$ using chloramine $T$ according to the method of Cuatrecasas (35). The method for determining specific ${ }^{125}$ I-insulin binding in human adipocytes was essentially similar to that described by Olefsky (36). The freshly isolated adipocytes at $20 \%$ lipocrit $(\approx 200,000$ cells $/ \mathrm{ml})$ were incubated with ${ }^{125} \mathrm{I}$-insulin $\left(1 \times 10^{-10} \mathrm{M}\right)$ in the absence and presence of increasing concentrations of unlabeled insulin for $2 \mathrm{~h}$ at $22^{\circ} \mathrm{C}$ in 10 $\mathrm{mM}$ Hepes-KRB buffer (pH 7.4) containing 3\% BSA and $2 \mathrm{mM}$ glu- 
cose. The cells were separated by centrifugation through silicone oil and the radioactivity counted. The nonspecific binding was consistently $<10 \%$ of the total binding and the degradation of ${ }^{125} \mathrm{I}$-insulin determined by TCA precipitation was also $<10 \%$ under assay conditions.

Primary culture of human adipocytes. The culture technique for isolated human adipocytes was a modification of the one described for isolated rat adipocytes $(37,38)$ and a recently described procedure for human adipocytes (39) with minor modifications. After the digestion of adipose tissue and cell isolation, collagenase was removed by washing the cells three times with $3 \%$ BSA-medium 199 containing penicillin $(100 \mathrm{U} / \mathrm{ml})$ and streptomycin $(100 \mu \mathrm{g} / \mathrm{ml})$. The cells were then suspended in the same medium in 1:10 ratio of cells and medium in sterile polypropylene $50-\mathrm{ml}$ conical tubes, loosely closed with screw caps, and incubated at $37^{\circ} \mathrm{C}$ for $24-48 \mathrm{~h}$ in a $5 \% \mathrm{CO}_{2}$-humidified atmosphere.

Exposure of primary cultures of adipocytes with insulin and washing procedure. The isolated adipocytes at $10 \%$ lipocrit were cultured in the absence and presence of $1 \times 10^{-10}$ - and $1 \times 10^{-7}$-M insulin concentrations for $24 \mathrm{~h}$ at $37^{\circ} \mathrm{C}$ in a $5 \% \mathrm{CO}_{2}$-humidified atmosphere. Under these incubation conditions, degradation of ${ }^{125}$ I-insulin at low as well as high insulin concentrations was $<20 \%$ and did not appreciably differ in different experimental groups. At the end of the incubation period, the receptor-bound insulin was dissociated by the modified method of Marshall and Olefsky (22). The entire washing procedure was carried out at $37^{\circ} \mathrm{C}$ with prewarmed and gassed buffers. First

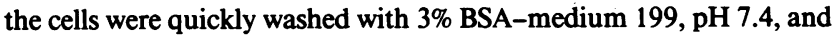
then incubated with $3 \%$ BSA-medium 199, $\mathrm{pH} 7.0$, for three 20-min intervals at $37^{\circ} \mathrm{C}$. After the third incubation, the cells were washed with glucose transport assay buffer $(10 \mathrm{mM}$ Hepes-KRB buffer, $\mathrm{pH}$ 7.4 , containing $3 \%$ BSA). This washing procedure effectively removed cell-associated insulin, and allowed the glucose transport system of insulin-stimulated adipocytes to deactivate. The cells from the three groups were then used to determine insulin sensitivity and responsiveness of glucose transport and specific ${ }^{125} \mathrm{I}$-insulin binding in the presence of varying insulin concentrations.

Statistical analysis. Descriptive statistics (mean \pm SEM) and comparative statistics (paired and unpaired Student's $t$ test) were performed using a computerized program (Stat View, the graphic statistics for the MacIntosh computer).

\section{Results}

Characterization of freshly isolated adipocytes. Basal and insulin-stimulated glucose transport was compared in freshly isolated adipocytes from nonobese-nondiabetic (control), morbidly obese subjects with normal GTT (obese NGTT), and morbidly obese patients with NIDDM (obese NIDDM) (Fig. 1). The basal glucose transport, expressed as glucose clearance rate per cell, in obese NGTT and obese NIDDM subjects, was significantly decreased when compared with that in controls $(P$ $<0.05)$. The maximal response of glucose transport at 1 $\times 10^{-7} \mathrm{M}$ insulin was significantly lower in obese NGTT and obese NIDDM subjects compared with that in controls. The differences in basal and insulin-stimulated glucose transport values between control and obese subjects were even more pronounced when the data were expressed by unit cell surface area or cell volume. Furthermore, the maximal response was also significantly decreased $(P<0.05)$ in NIDDM subjects when compared with age-, weight-, and sex-matched subjects with normal GTT. When analyzed as percent change above basal glucose transport in response to different insulin concentrations (Fig. 1, top), the decrease of insulin responsiveness in obesity and NIDDM was also evident. Although, the $50 \%$ effective dose $\left(E D_{50}\right)$ of insulin-stimulated glucose transport

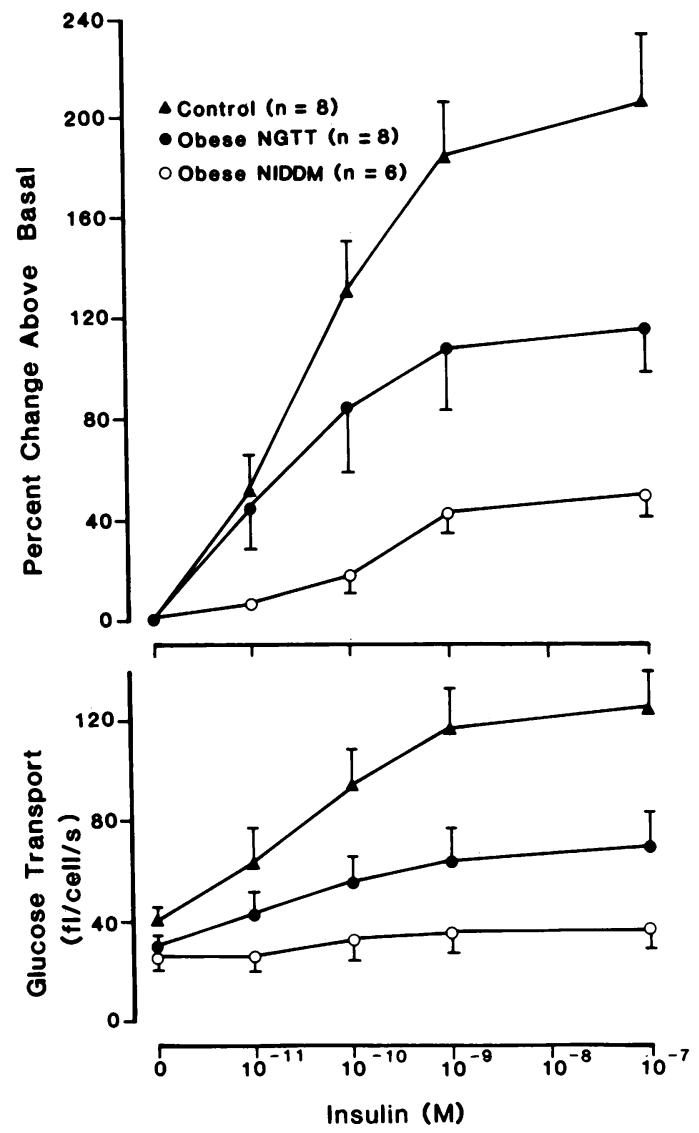

Figure 1. Glucose transport was determined at tracer $\left[{ }^{14} \mathrm{C}-\mathrm{U}\right] \mathrm{glucose}$ concentration $(500 \mathrm{nM})$ in the absence and presence of different insulin concentrations in freshly isolated adipocytes from control, obese NGTT, and obese NIDDM subjects. (Bottom) Net glucose transport expressed as glucose clearance rate (femtoliters per cell per second) in the absence and presence of insulin. (Top) Percent change above basal glucose transport in response to different insulin concentrations.

was similar in control and obese subjects with normal glucose tolerance, it was significantly higher in obese NIDDM subjects. The percent specific ${ }^{125} \mathrm{I}$-insulin binding per 50,000 adipocytes at tracer concentration was significantly lower in obese NGTT compared with that in nonobese-nondiabetic controls $(\dot{P}<0.05)$, but it was not statistically different in the presence of increasing concentration of unlabeled insulin (Fig. 2). However, when the data were expressed by cell surface area, the specific ${ }^{125} \mathrm{I}$-insulin binding at every insulin concentration was significantly lower in obese subjects. Thus, insulin receptor density was less on the cell surface of adipocytes from obese subjects in comparison with nonobese controls. The percent specific ${ }^{125} \mathrm{I}$-insulin binding at various insulin concentrations was further decreased in obese NIDDM, even when the data is expressed by cell number and was also significantly lower in comparison to obese controls (Fig. 2). The data in freshly isolated adipocytes from this patient population largely confirm other studies on insulin-stimulated glucose transport and insulin binding from obese patients with and without NIDDM $(3,4,33,36,40-44)$.

These data on glucose transport and insulin binding in freshly isolated adipocytes from control, obese NGTT, and 


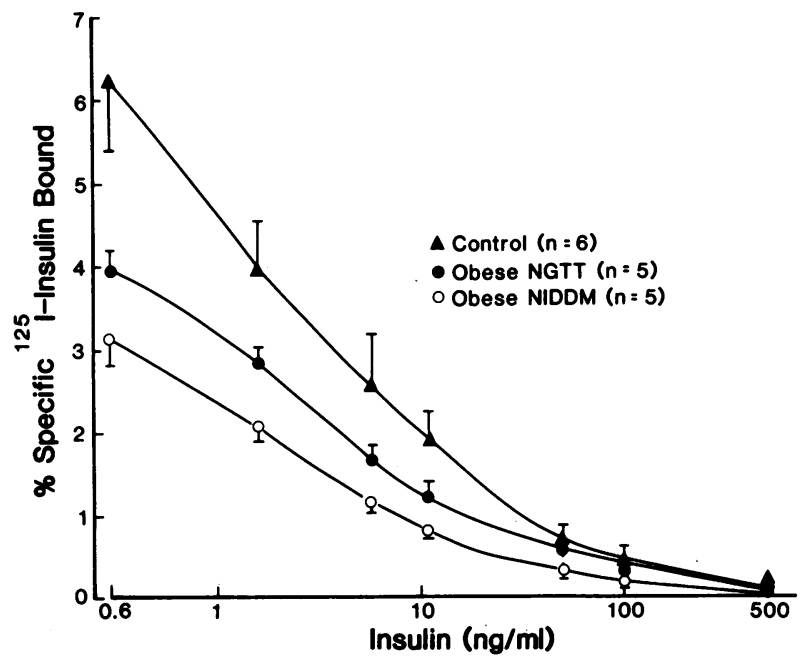

Figure 2. Competition curves of specific ${ }^{125} \mathrm{I}$-insulin binding in freshly isolated adipocytes $(200,000$ cells $/ \mathrm{ml})$ from control, obese NGTT, and obese NIDDM subjects.

obese NIDDM subjects, taken together, serve to illustrate that the simple inverse relationship between circulating insulin levels and insulin binding ("down-regulation"), and the prediction from the insulin dose-response curves of insulin receptor defect (increased $\mathrm{ED}_{50}$ ) or postreceptor defects (decreased maximum velocity), may not always be valid. For example, the basal insulin concentration in our obese patients with or without diabetes is identical, but the glucose-stimulated insulin release is markedly decreased in diabetics, yet insulin binding is decreased. Also, $\mathrm{ED}_{50}$ of insulin for glucose transport is similar in obese NGTT patients to that in controls even though specific ${ }^{125} \mathrm{I}$-insulin binding at tracer $\left(1 \times 10^{-10} \mathrm{M}\right)$ concentration is decreased in the obese patients when expressed either by cell number or by unit cell surface area.

Development of primary cultures of insulin responsive human adipocytes. To understand the possible mechanism(s) of insulin resistance, we have established a primary culture system of human adipocytes in our laboratory. However, before we can use these cultures effectively, we should be able to demonstrate that adipocytes from both control and obese patients with or without NIDDM are morphologically and biochemically similar before and after culture.

We have observed that high BSA concentration in the culture medium and large surface area of cells exposed to the medium as described in the methodology section significantly minimize the disruption of cells during long-term incubation periods. Exposure of adipocytes with low concentrations of collagenase $(0.5 \mathrm{mg} / \mathrm{ml})$ during isolation procedure also contributed to minimizing cell disruption during culture. The lysis of fat cells during culture was assessed by comparing the ratio of oil (mainly produced by breakage of fat cells) and total fat cell volume. The lysis was $<5 \%$ of total cell volume in control, obese NGTT, and obese NIDDM subjects after 24- or 48-h culture. Fig. 3 is a histogram of percent distribution of fat cells of different sizes from three obese subjects in freshly isolated, 24- and 48-h cultured adipocytes. Thus, no preferential breakage of larger fat cells was observed at any stage during 48-h culture. Similarly, we did not observe preferential breakage of any particular size fat cells from control and obese NIDDM

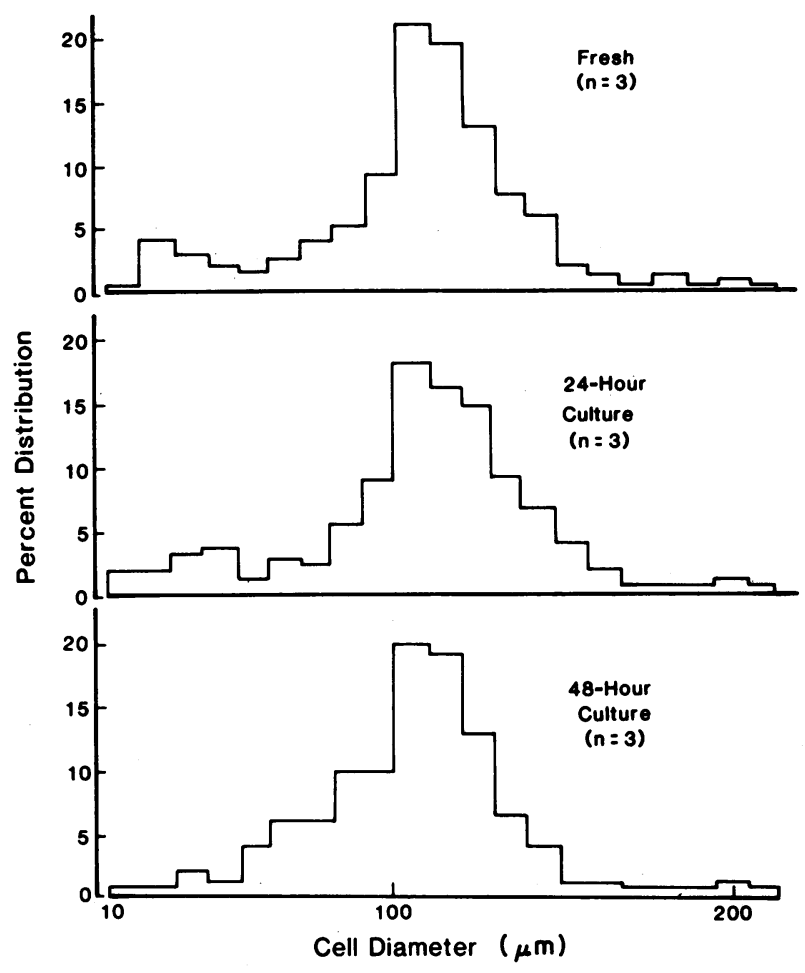

Figure 3. Percent distribution of different size cells from obese NGTT subjects immediately after isolation (top), after 24-h (middle), and after 48-h (bottom) culture.

subjects. The $\left[{ }^{14} \mathrm{C}\right]$ leucine incorporation into proteins was similar in fat cells cultured in $10 \%$ fetal bovine serum or $3 \%$ BSA without fetal bovine serum. The ability to culture human adipocytes in a chemically defined medium offers a distinct advantage over the cells cultured in fetal bovine serum in the presence of complicating hormonal factors.

To further validate our culture system, we have compared insulin binding and glucose transport in freshly isolated and 24-h cultured adipocytes. In control subjects, specific ${ }^{125} \mathrm{I}$-insulin binding at different insulin concentrations was similar in freshly isolated or 24-h cultured adipocytes (Fig. 4, top). Although the percent specific ${ }^{125} \mathrm{I}$-insulin binding at tracer insulin concentration in 24-h cultured cells decreased slightly in obese NGTT (Fig. 4, middle) and obese NIDDM (Fig. 4, bottom) subjects, the differences were not significant. Specific ${ }^{125} \mathrm{I}$-insulin binding in the presence of different insulin concentrations was not significantly different in fresh and cultured cells in the two obese groups. There were no significant alterations in either basal or insulin-stimulated glucose transport values in freshly isolated and 24-h cultured adipocytes from two obese groups (Fig. 5, middle and bottom). Although no significant differences were observed in basal or insulin-stimulated glucose transport between fresh and 24-h cultured adipocytes from control subjects, insulin responsiveness appeared to slightly decrease during culture (Fig. 5, top). More importantly, the differences among the three experimental groups in regard to stimulation of glucose transport of freshly isolated adipocytes are well preserved even after 24 -h primary culture. Our preliminary observations of $\left[{ }^{14} \mathrm{C}-\mathrm{U}\right] \mathrm{glucose}$ oxidation and $\left[{ }^{14} \mathrm{C}\right.$-U]glucose incorporation into triglycerides under basal and $1 \times 10^{-7} \mathrm{M}$ insulin-stimulated conditions in freshly iso- 


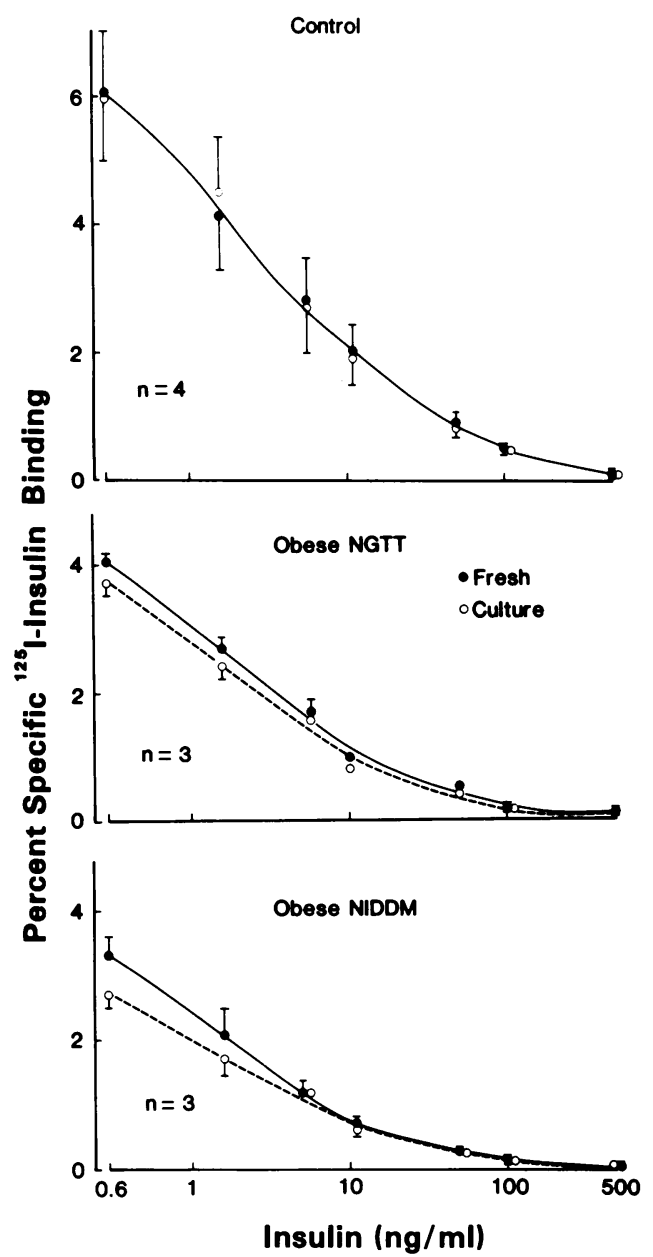

Figure 4. After isolation of adipocytes, one-half of the cells were immediately used for determining specific ${ }^{125} \mathrm{I}$-insulin binding. The remaining cells were cultured for $24 \mathrm{~h}$ in 3\% BSA-medium 199, washed with 3\% BSA-10 mM Hepes-KRB buffer, $\mathrm{pH} 7.4$, and specific ${ }^{125} \mathrm{I}$-insulin binding determined in the absence and presence of different insulin concentrations under identical conditions as in fresh cells.

lated and 24-h cultured adipocytes from obese NGTT and obese NIDDM subjects, demonstrate that cultured cells also respond to insulin for these two insulin actions (data not shown).

Effects of 24-h exposure of insulin on glucose transport and ${ }^{125}$ I-insulin binding in primary cultures of human adipocytes. We investigated the possibility that insulin improves insulin sensitivity in adipocytes from insulin-resistant states such as NIDDM and obesity. The effects of a 24-h insulin exposure on basal and insulin-stimulated glucose transport in cultured adipocytes from nonobese control, obese NGTT, and obese NIDDM subjects are shown in Figs. 6, 7, and 8, respectively. In the three study groups, basal glucose transport decreased in cells treated for $24 \mathrm{~h}$ with $1 \times 10^{-10}$ and $1 \times 10^{-7} \mathrm{M}$ insulin, though the differences from buffer-treated cells were significant only in $1 \times 10^{-7} \mathrm{M}$ insulin-treated cells $(P<0.05-0.01$ for paired $t$ test). In the three patient groups, insulin-stimulated glucose transport was lower in $1 \times 10^{-10} \mathrm{M}$ insulin-treated cells in comparison with buffer-treated cells, though these differences were not significant. However, this trend in decreased insulin-stimulated glucose transport was evident in cells

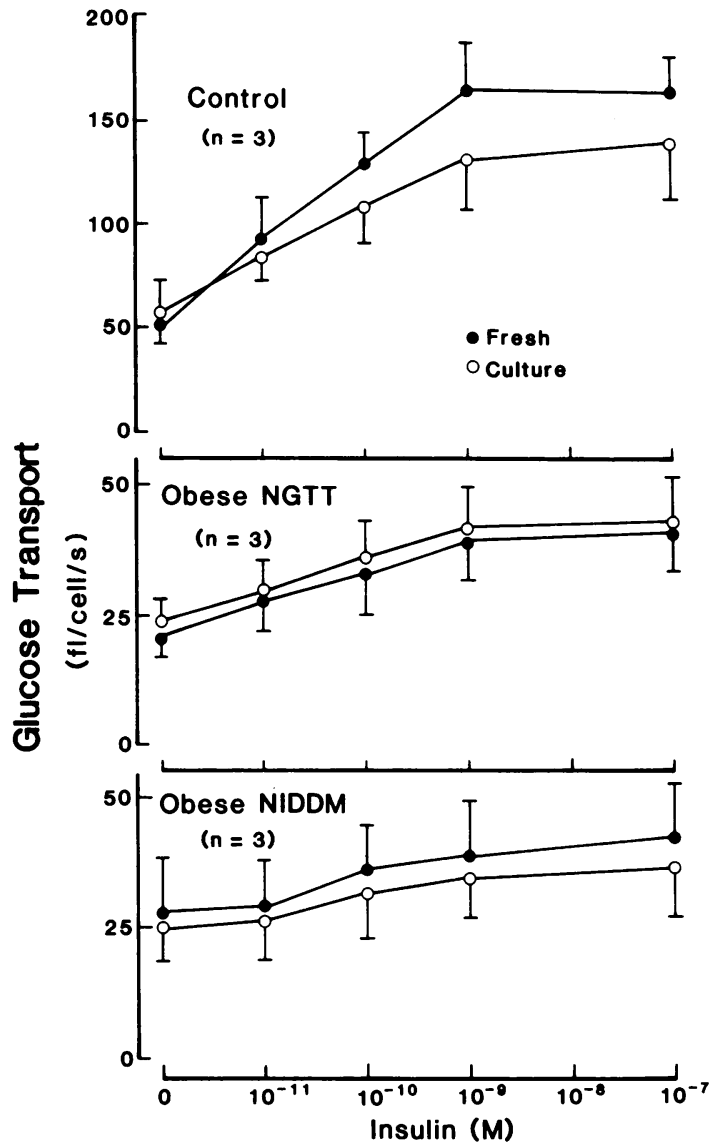

Figure 5. After isolation of adipocytes, one-half of the cells were immediately used for determining basal and insulin-stimulated glucose transport. The remaining cells were cultured for $24 \mathrm{~h}$ in $3 \%$ BSAmedium 199, washed with 3\% BSA-10 mM Hepes-KRB buffer, $\mathrm{pH}$ 7.4 , and then basal and insulin-stimulated glucose transport determined.

treated with high insulin $\left(1 \times 10^{-7} \mathrm{M}\right)$. In controls, the percent change above basal in the presence of different insulin concentrations was significantly decreased in $1 \times 10^{-7} \mathrm{M}$ insulintreated cells in comparison with those in buffer-treated cells $(P$ $<0.05$, paired $t$ test) (Fig. 6). In obese NGTT subjects, significant reductions in glucose transport stimulated by different concentrations of insulin in cells previously treated with 1 $\times 10^{-7} \mathrm{M}$ were observed for net values and percent change above basal glucose transport (Fig. 7). Similar to nonobese and obese subjects with normal glucose tolerance, treatment of adipocytes from diabetic subjects with $1 \times 10^{-7} \mathrm{M}$ insulin resulted in significant reduction in net values, as well as percent change above basal glucose transport in response to different insulin concentrations (Fig. 8). In addition to decreased insulin responsiveness, we also observed a significant reduction in insulin sensitivity of $1 \times 10^{-7} \mathrm{M}$ insulin-treated adipocytes compared with buffer-treated adipocytes from obese NIDDM $\left(E_{50}\right.$ of insulin, $3.92 \pm 0.62$ vs. $1.86 \pm 0.37 \times 10^{-10}$ $M)$, obese NGTT $(6.39 \pm 2.77$ vs. $0.31 \pm 0.09)$, and control $(1.84 \pm 0.08$ vs. $0.21 \pm 0.08)$ subjects. Our results of insulin's effect on glucose transport clearly demonstrate that insulin alters both insulin sensitivity and responsiveness of adipocytes from control as well as obese and NIDDM subjects.

Utilizing these cultured adipocytes, we also investigated the 

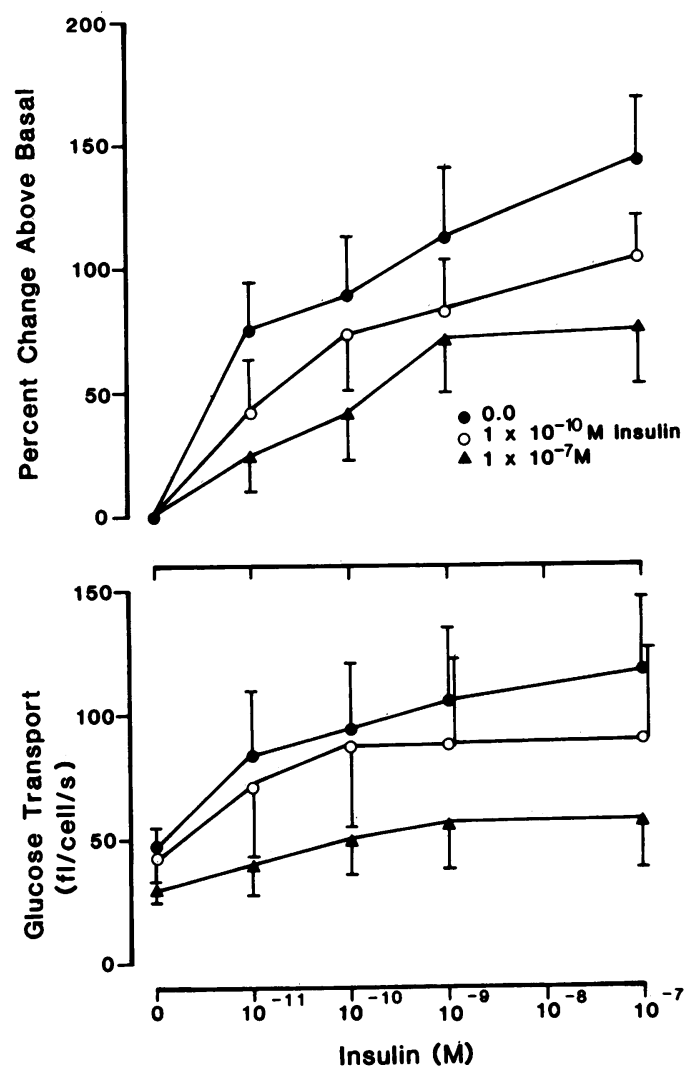

Figure 6. Control. After isolation of the adipocytes from control subjects $(n=5)$, the cells were divided into three equal parts and cultured in 3\% BSA-medium 199 for $24 \mathrm{~h}$ in the absence $(\bullet)$ and presence of $1 \times 10^{-10} \mathrm{M}$ insulin (0) and $1 \times 10^{-7} \mathrm{M}$ insulin ( $\triangle$ ). The cellassociated insulin was removed by three 20 -min incubations with $3 \%$ BSA-medium 199, pH 7.0, followed by washings with 3\% BSA-10 $\mathrm{mM}$ Hepes-KRB buffer, $\mathrm{pH}$ 7.4. The basal and insulin-stimulated glucose transport were then determined simultaneously in three groups. (Bottom) Net glucose transport. (Top) Percent change above basal glucose transport in response to different insulin concentrations.

effect of insulin on specific ${ }^{125}$ I-insulin binding in the presence of different concentrations of unlabeled insulin (Fig. 9). In all three groups, exposure of adipocytes for $24 \mathrm{~h}$ with physiological concentration of insulin $\left(1 \times 10^{-10} \mathrm{M}\right)$ resulted in a $\sim 20 \%$ decrease in specific ${ }^{125}$ I-insulin binding only at tracer insulin concentration over buffer-treated cells. However, when the cells were treated with $1 \times 10^{-7} \mathrm{M}$ insulin, the decreases in ${ }^{125}$ I-insulin binding at tracer insulin concentration were more pronounced. In $1 \times 10^{-7} \mathrm{M}$ insulin-treated cells, significant reductions in specific ${ }^{125}$ I-insulin binding were also observed with respective controls, i.e., buffer-treated cells in the presence of different concentrations of unlabeled insulin in control $(1.6,10,50$, and $100 \mathrm{ng} / \mathrm{ml}$ insulin), obese NGTT $(1.6,10,50$, 100 , and $500 \mathrm{ng} / \mathrm{ml}$ insulin), and obese NIDDM $(1.6,10,50$, 100 , and $500 \mathrm{ng} / \mathrm{ml}$ insulin) subjects. Due to the limitations of Scathard analyses, it may be more appropriate to suggest that insulin-induced down-regulation of insulin binding was mainly due to decrease in receptor number in all three groups.

\section{Discussion}

To test the hypothesis that insulin induces insulin resistance in normal cells but improves insulin sensitivity in insulin-resis-

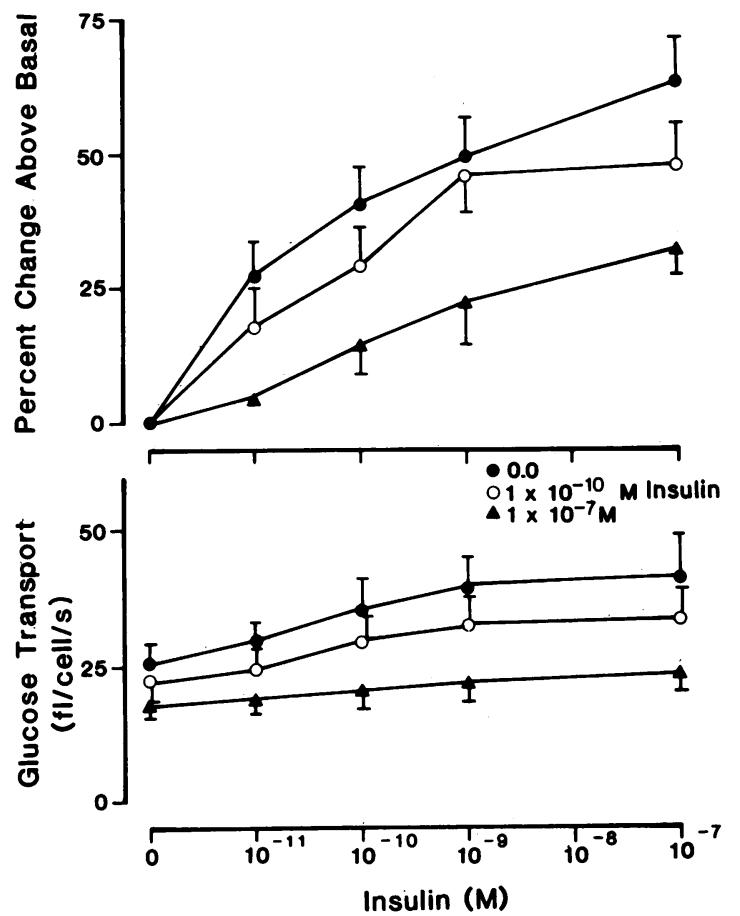

Figure 7. Obese NGTT. Effect of insulin on basal and insulin-stimulated glucose transport in adipocytes from obese NGTT subjects ( $n$ $=7$ ) after 24-h culture in the absence $(\bullet)$ and presence of $1 \times 10^{-10}$ $\mathrm{M}$ insulin (0) and $1 \times 10^{-7} \mathrm{M}$ insulin ( 4 ). The details of experimental protocol were similar to those described for Fig. 6 .

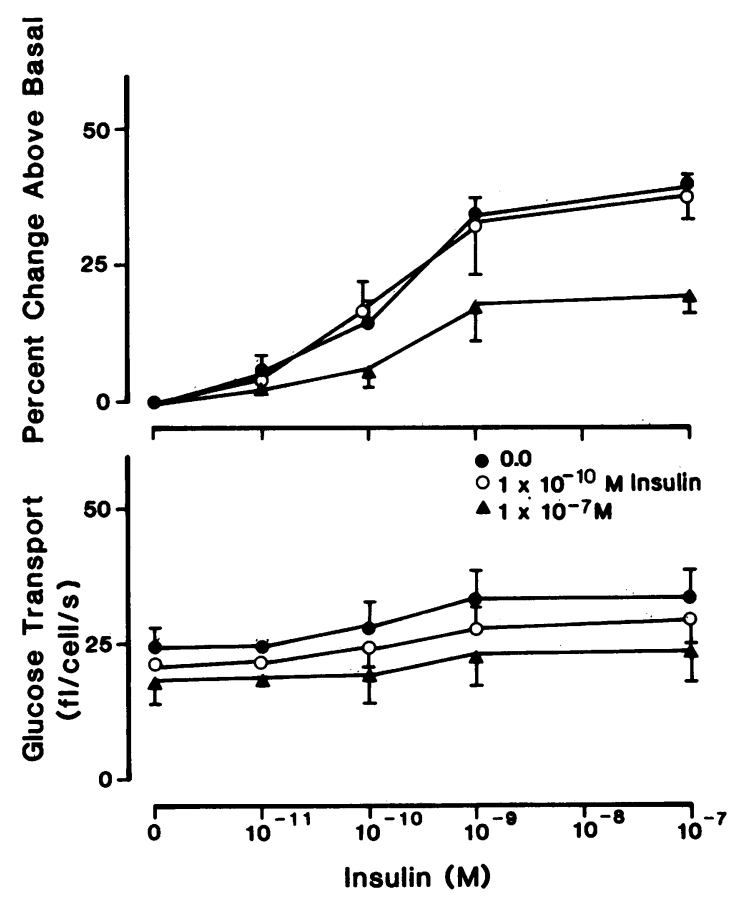

Figure 8. Obese NIDDM. Effect of insulin on basal and insulin-stimulated glucose transport in adipocytes from obese NIDDM subjects $(n=5)$ after 24-h culture in the absence $(\bullet)$ and presence of 1 $\times 10^{-10} \mathrm{M}$ insulin (o) and $1 \times 10^{-7} \mathrm{M}$ insulin ( $\Delta$ ). The details of experimental protocol were similar to those described for Fig. 6. 


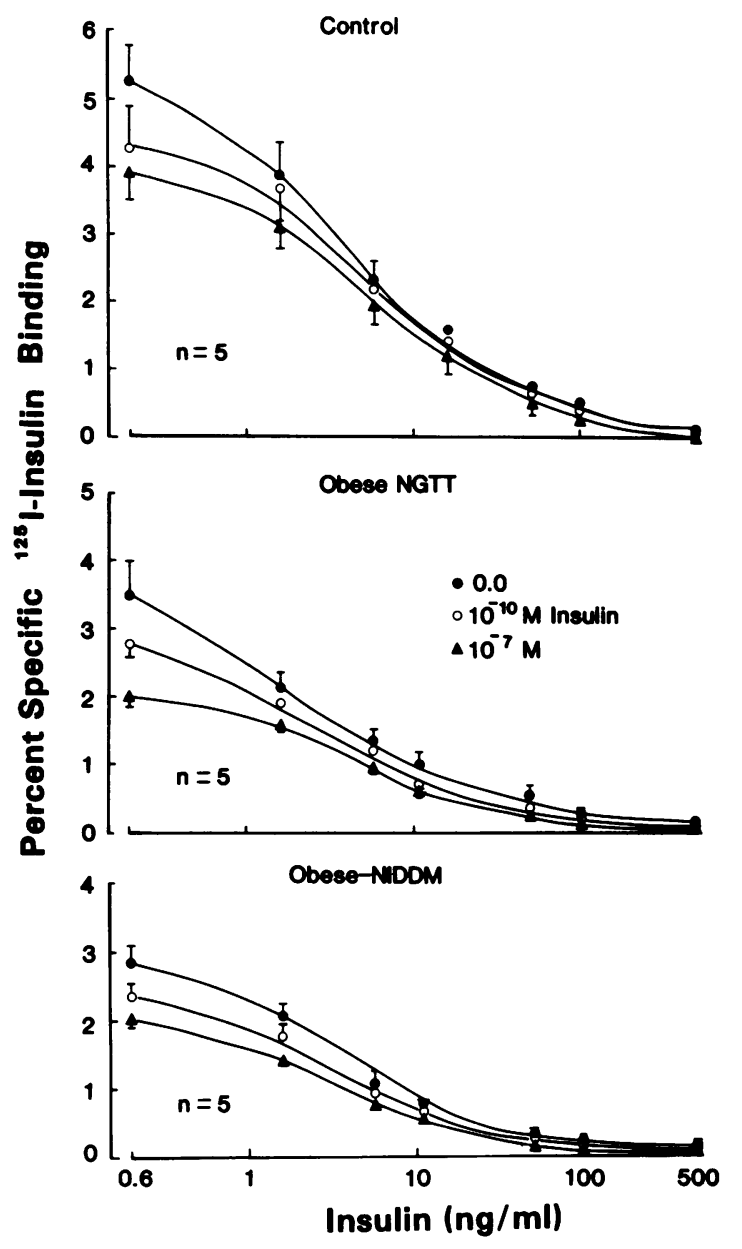

Figure 9. Competition curves of specific ${ }^{125}$ I-insulin binding in adipocytes from five control (top), five obese NGTT (middle), and five obese NIDDM (bottom) subjects after 24-h culture in the absence (•) and presence of $1 \times 10^{-10} \mathrm{M}$ insulin (o) and $1 \times 10^{-7} \mathrm{M}$ insulin ( $\Delta$ ). The details of the experimental protocol were similar to those described for Fig. 6.

tant cells, we have ( $a$ ) characterized a population of patients with and without varying degrees of insulin resistance with regards to glucose transport and insulin binding in freshly isolated adipocytes; $(b)$ developed a primary culture of human adipocytes that maintains the same degree of insulin resistance as do the freshly isolated adipocytes; and $(c)$ tested the effects of a 24-h exposure of physiological and high concentrations of insulin in primary culture of adipocytes from these patient populations.

The data in freshly isolated adipocytes from this patient population largely confirm other studies on insulin action and insulin binding from obese patient with and without NIDDM $(3,4,33,36,40-44)$. The benefits of using cultured adipocytes and human or rat adipose tissue pieces to identify regulatory mechanism(s) of insulin receptors and insulin action is well established (20, 37, 38, 45-49). A report using cultured human adipocytes from normal subjects has appeared (39). However, insulin sensitivity and responsiveness were not established by these investigators (39). The significance of the cell system described in this report is twofold. First, the cultures of human adipocytes are insulin responsive with regard to glucose transport and metabolism. Second, and most important, adipocytes from normal and insulin-resistant patients maintain the original characteristics of freshly isolated adipocytes in culture. The 24-h insulin exposure of cultured human adipocytes decreased insulin sensitivity and responsiveness. These decreases are similar in control, obese NGTT, and obese NIDDM patients. Also, the extent of down-regulation of the insulin receptor by insulin under in vitro conditions was similar in the three groups of patients. We have previously proposed that the regulation of the cell surface insulin receptors is one of the many biological actions of insulin (19). Thus, if a cell is resistant to this function of insulin, the number of insulin receptors might be normal or even high in the presence of hyperinsulinemia. The present study demonstrates that adipocytes which are resistant to insulin with regard to glucose transport are normally responsive to the ability of insulin to down-regulate insulin receptors. Kashiwagi et al. (33) have also demonstrated that adipocytes from NIDDM patients which were resistant to insulin with regard to glucose transport were normally responsive to insulin with regard to inhibition of lipolysis.

Our study does not provide any clue as to the mechanism of induced insulin resistance by prolonged exposure to insulin. Clearly, it is not only due to insulin receptor loss. Furthermore, the recent studies by Marshall et al. (38) and Garvey et al. $(48,49)$, using rat adipocytes, demonstrate that changes in insulin action may precede any change in insulin binding. We and others have demonstrated in cultured rat hepatocytes $(50)$, adipocytes (51), and hepatoma cells (52) that chronic exposure of cells to insulin decreases the intrinsic activity of the insulin receptor kinase. Furthermore, adipose tissue of similar morbidly obese patients with NIDDM shows a defect in the insulin receptor kinase activity (53). Thus, insulin-induced resistance may be due to the inactivation of the insulin receptor kinase or any of the other postinsulin binding events that are believed to be important for the mediation of insulin action (54-57).

The different results between previously published reports regarding the improved in vivo (6-9) and in vitro $(10,11)$ sensitivity to insulin in NIDDM patients after insulin treatment, and the present study demonstrating a worsening of insulin resistance by insulin in cultured adipocytes of NIDDM patients, is of interest. The different duration of insulin exposure could be the explanation. However, it seems appropriate to speculate that for insulin to have a beneficial effect on insulin sensitivity, the interaction with other hormones or factors that are absent in serum-free medium may be crucial. Furthermore, it may not be insulin per se, but another factor that is induced by insulin in NIDDM patients that may be enhancing insulin sensitivity. Amatruda et al. (58) have previously shown that in nonketotic streptozotocin diabetic rats administration of insulin improved insulin action in the liver. In contrast, in vitro insulin exposure of primary cultures of hepatocytes from these same diabetic insulin-resistant animals did not result in an improved insulin response (58). The factor(s) that regulate insulin action are largely unknown. However, the cell model described here with human cells in culture from normal and insulin-resistant subjects should facilitate the search of the mechanism(s) that modulate insulin action in man.

\section{Acknowledgments}

We thank Dr. Kirk Ways for critical review of the manuscript and Carmen Archibald and Lisa Bradley for their skillful word processing assistance. 
This work was supported in part by research grants from Diabetes Research and Education Foundation and from National Institutes of Health grants R01-AM32585-05 and P01DK3296.

\section{References}

1. Ginsberg, H., G. Kimmerling, J. M. Olefsky, and G. M. Reaven. 1975. Demonstration of insulin resistance in untreated adult-onset diabetic subjects with fasting hyperglycemia. J. Clin. Invest. 55:454461.

2. Rizza, R. A., L. J. Mandarino, and J. E. Gerich. 1981. Mechanism and significance of insulin resistance in non-insulin-dependent diabetes mellitus. Diabetes. 30:990-995.

3. Kolterman, O. G., R. S. Gray, J. Griffin, P. Bernstein, J. Insel, J. A. Scarlett, and J. M. Olefsky. 1981. Receptor and post receptor defects contribute to the insulin resistance in non-insulin-dependent diabetes mellitus. J. Clin. Invest. 68:957-969.

4. DeFronzo, R. A., A. D. Deibert, R. Hendler, P. Felig, and V. J. Soman. 1979. Insulin sensitivity and insulin binding to monocytes in maturity-onset diabetes. J. Clin. Invest. 63:939-936.

5. Bogardus, C., S. Lillioja, B. V. Howard, G. Reaven, and D. Mott. 1984. Relationship between insulin secretion, insulin action, and fasting plasma glucose concentration in nondiabetic and noninsulin-dependent diabetic subjects. J. Clin. Invest. 74:1238-1246.

6. Donner, C. C., E. Fraze, Y.-D. I. Chen, and G. M. Reaven. 1985. Quantitation of insulin-stimulated glucose disposal in patients with noninsulin-dependent diabetes mellitus. Diabetes. 34:831-835.

7. Firth, R., P. M. Bell, and R. A. Rizza. 1986. Effects of tolazamide and exogenous insulin action in patients with noninsulin-dependent diabetes mellitus. $N$. Engl. J. Med. 314:1280-1286.

8. Scarlett, J. A., R. S. Gray, J. Griffin, J. M. Olefsky, and O. G. Kolterman. 1982. Insulin treatment reverses the insulin resistance of type II diabetes mellitus. Diabetes Care. 5:353-363.

9. Reaven, G. M., Y. I. Chen, A. M. Coulston, M. S. Greenfield, C. Hollenbeck, C. Lardinois, G. Liu, and H. Schwartz. 1983. Insulin secretion and action in noninsulin-dependent diabetes mellitus. Is insulin resistance secondary to hypoinsulinemia? Am. J. Med. 75(Suppl. 5B):85-93.

10. Scarlett, J. A., O. G. Kolterman, T. P. Ciaraldi, M. Kao, and J. M. Olefsky. 1983. Insulin treatment reverses the post receptor defect in adipocyte 3-O-methyl glucose transport in type II diabetes mellitus. J. Clin. Endocrinol. Metab. 56:1195-1201.

11. Foley, J. E., A. Kashiwagi, M. A. Verso, G. Reaven, and J. Andrews. 1983. Improvement in in vitro insulin action after one month therapy in obese non-insulin-dependent diabetes. J. Clin. Invest. 72:1901-1909.

12. Kobayashi, M., and J. M. Olefsky. 1978. Long-term regulation of adipocyte glucose transport capacity by circulating insulin in rats. $J$. Clin. Invest. 62:73-81.

13. Wardzala, L. J., M. Hirshman, E. Pofcher, E. D. Horton, P. M. Mead, S. W. Cushman, and E. S. Horton. 1985. Regulation of glucose utilization in adipose cells and muscle after long-term experimental hyperinsulinemia in rats. J. Clin. Invest. 76:460-469.

14. Trimble, E. R., G. C. Weir, A. Gjinovci, F. AssimacopoulosJeannet, R. Benzi, and A. E. Renold. 1984. Increased insulin responsiveness in vivo and in vitro consequent to induced hyperinsulinemia in the rat. Diabetes. 33:444-449.

15. Czech, M. P., D. K. Richardson, S. G. Becker, C. G. Walters, W. Gitomer, and J. Heinrich. 1978. Insulin response in skeletal muscle and fat cells of the genetically obese Zucker rat. Metab. Clin. Exp. 27:1967-1981.

16. Cushman, S. W., M. J. Zarnowski, M. J. Franzusoff, and L. B. Salans. 1978. Alterations in glucose metabolism and its stimulation by insulin in isolated adipose cells during the development of genetic obesity in the Zucker fatty rat. Metab. Clin. Exp. 27:1930-1940.

17. Gavin, J. R. III, J. Roth, D. M. Neville, P. DeMeyts, and D. Buell, 1974. Insulin dependent regulation of insulin receptor concen- trations. A direct demonstration in cell culture. Proc. Natl. Acad. Sci. USA 71:84-88.

18. Blackard, W. G., P. S. Guzelian, and M. E. Small. 1978. Down regulation of insulin receptors in primary cultures of adult rat hepatocytes in monolayer. Endocrinology. 103:548-553.

19. Caro, J. M., and J. M. Amatruda. 1980. Insulin receptors in hepatocytes: post receptor events mediated down regulation. Science (Wash. DC). 210:1029-1031.

20. Livingston, J., B. Purvis, and D. H. Lockwood. 1978. Insulin dependent regulation of insulin sensitivity of adipocytes. Nature (Lond.). 273:394-396.

21. Mott, D. M., B. V. Howard, and P. H. Bennett. 1979. Stoichiometric binding and regulation of insulin receptors on human diploid fibroblasts using physiologic insulin levels. J. Biol. Chem. 254:87628767.

22. Marshall, S., and J. M. Olefsky. 1980. Effects of insulin incubation on insulin binding, glucose transport, and insulin degradation by isolated rat adipocytes. J. Clin. Invest. 66:763-771.

23. Amatruda, J., H. W. Newmeyer, and C. L. Chang. 1982. Insulin induced alterations in insulin binding and action in primary culture of rat hepatocytes. Diabetes. 31:145-148.

24. Davidson, M. and E. D. Casanello. 1979. Insulin antagonism in cultured rat myoblasts secondary to chronic exposure to insulin. Horm. Metab. Res. 11:207-209.

25. Chen, R. F. 1967. Removal of fatty acids from serum albumin by charcoal treatment. J. Biol. Chem. 242:173-181.

26. Brown, E. K., E. A. Settle, and A. M. VanRij. 1982. Food intake patterns of gastric bypass patients. J. Am. Diet. Assoc. 80:439443.

27. National Diabetes Data Group. 1979. Classification and progress of diabetes mellitus and other categories of glucose intolerance. Diabetes 23:1039-1056.

28. Soeldner, J. J. 1971. The intravenous glucose tolerance test. In Diabetes Mellitus: Diagnosis and Treatment. Vol. III. S. S. Fajans and K. E. Susman, editors. American Diabetes Association, Inc., New York. 107-114.

29. Rodbell, M. 1964. Metabolism of isolated fat cells. 1. Effects of hormones on glucose metabolism and lipolysis. J. Biol. Chem. 239:375-380.

30. Pedersen, O., E. Hjollund, H. Beck-Nielsen, H. O. Lindskov, O. Sonne, and J. Gliemann. 1981. Insulin receptor binding and receptormediated insulin degradation in human adipocytes. Diabetologia. 20:636-641.

31. Goldrick, R. B. 1967. Morphological changes in the adipocyte during fat deposition and mobilization. Am. J. Physiol. 212:777-781.

32. Hirsch, J., and B. Batchelor. 1976. Adipose tissue cellularity in human obesity. Clin. Endocrinol. Metab. 5:299-307.

33. Kashiwagi, M., A. Verso, J. Andrews, B. Vasquez, G. Reaven, and J. E. Foley. 1983. In vitro insulin resistance of human adipocytes isolated from subjects with non-insulin-dependent diabetes mellitus. J. Clin. Invest. 72:1246-1254.

34. Ciaraldi, T. P., O. G. Kolterman, J. A. Siegel, and J. M. Olefsky. 1979. Insulin stimulated glucose transport in human adipocytes. Am. J. Physiol. 236:E621-E625.

35. Cuatrecasas, P. 1971. Insulin-receptor interaction in adipose tissue cells: direct measurement and properties. Proc. Natl. Acad. Sci. USA 68:1264-1268.

36. Olefsky, J. M. 1976. Decreased insulin binding to adipocytes and circulating monocytes from obese subjects. J. Clin. Invest. 57:1165-1172.

37. Marshall, S. 1983. Kinetics of insulin receptor biosynthesis and membrane insertion: relationship to cellular function. Diabetes. 32:319-325.

38. Marshall, S., W. T. Garvey, and M. Geller. 1984. Primary culture of isolated adipocytes. A new model to study insulin receptor regulation and insulin action. J. Biol. Chem. 259:6376-84.

39. Kern, P. A., S. Marshall, and R. H. Eckel. 1985. Regulation of 
lipoprotein lipase in primary cultures of isolated human adipocytes. $J$. Clin. Invest. 75:199-208.

40. Harrison, L. C., F. I. R. Martin, ard R. A. Melick. 1976. Correlation between insulin receptor binding in isolated fat cells and insulin sensitivity in obese human subjects. J. Clin. Invest. 58:14351441.

41. Misbin, R. I., J. P. O'Leary, and A. Pulkkinen. 1979. Insulin receptor in obesity: a reassessment. Science (Wash. DC). 205:10031004.

42. Lonnroth, P., M. DiGirolamo, M. Krotiewski, and U. Smith. 1983. Insulin binding and responsiveness in fat cells from patients with reduced glucose tolerance and type II diabetes. Diabetes. 32:748-754.

43. Pedersen, O., E. Hjollund, and N. Schwartz. 1982. Insulin receptor binding and insulin action in human fat cells: effects of obesity and fasting. Metab. Clin. Exp. 31:884-895.

44. Olefsky, J. M., O. G. Kolterman, and J. A. Scarlett. 1982. Insulin action and resistance in obesity and noninsulin dependent type II diabetes mellitus. Am. J. Physiol. 243:E15-E30.

45. Cigolini, M., and U. Smith. 1979. Human adipose tissue in culture. VIII. Studies on the insulin-antagonistic effect of glucocorticoids. Metab. Clin. Exp. 28:502-510.

46. Lonnroth, P., M. DiGirolamo, and U. Smith. 1983. Influence of ambient glucose and insulin concentrations on adipocyte insulin binding. Metab. Clin. Exp. 32:609-614.

47. Simpson, I. A., J. A. Hedo, and S. W. Cushman. 1984. Insulininduced internalization of insulin receptor in the isolated rat adipose cells. Detection of both major receptor subunits following their biosynthetic labelling in culture. Diabetes. 33:13-18.

48. Garvey, W. T., J. M. Olefsky, and S. Marshall. 1985. Insulin induces progressive insulin resistance in cultured rat adipocytes: sequential effects at receptor and multiple post receptor sites. Diabetes. 35:258-267.

49. Garvey, T. W., J. M. Olefsky, and S. Marshall. 1986. Insulin receptor down-regulation is linked to an insulin-induced postreceptor defect in the glucose transport system in rat adipocytes. J. Clin. Invest. 76:22-30.

50. Sinha, M. K., O. Ittoop, M. Jenquin, and J. F. Caro. 1985. Effect of down-regulation and tunicamycin on insulin receptor autophosphorylation and kinase activity. Diabetes. 34(Suppl. 1):159A.

51. Arsenis, G., and J. N. Livingston. 1986. Alterations in the tyrosine kinase activity of the insulin receptor produced by in vitro hyperinsulinemia. J. Biol. Chem. 261:147-153.

52. Kahn, C. R., M. Crettaz, F. Grigorescu, S. Takayama, O. P. Ganda, and J. S. Fleir. 1984. The role of insulin receptor kinase activity in insulin action: implications from insulin resistant states: In Endocrinology. F. Labrie and L. Proulx, editors. Excerpta Medica, Inc., Princeton, NJ. 249-256.

53. Sinha, M. K., W. J. Pories, E. G. Flickinger, D. Meelheim, and J. F. Caro. 1987. Insulin receptor kinase activity of adipose tissue from morbidly obese humans with and without noninsulin-dependent diabetes. Diabetes. 36:620-625.

54. Larner, J., G. Galasko, K. Cheng, A. A. DePaoli-Roach, L. Huange, P. Daggy, and J. Kellog. 1979. Generation by insulin of a chemical mediator that controls protein phosphorylation and dephosphorylation. Science (Wash. DC). 206:1408-1410.

55. Jarett, L., and J. R. Seals. 1979. Pyruvate dehydrogenase activation in adipocyte mitochondria by an insulin-generated mediator from muscle. Science (Wash. DC). 206:1407-1408.

56. Pershadsingh, H. A., and J. M. McDonald. 1979. Direct addition of insulin inhibits a high affinity $\mathrm{Ca}^{++}$-ATPase in isolated adipocyte plasma membrane. Nature (Lond.). 281:495-497.

57. Farese, R. V., T. S. Konda, J. S. Davis, M. L. Standarert, R. J. Pollet, and D. R. Cooper. 1987. Insulin rapidly increases diacylglycerol by activating de novo phosphatidic acid synthesis. Science (Wash. DC). 236:586-589.

58. Amatruda, J. M., and C. L. Chang. 1983. The regulation of lipid synthesis in primary cultures of hepatocytes from nonketotic striptozotocin diabetic rats. Metab. Clin. Exp. 32:224-229. 